17 Lowe GDO, Rumely A, Sweetnam PM, Yarnell JWG. Fibrin D-dimer, C-reactive protein and risk of ischaemic heart disease: the Speedwell study. Blood Coagul Fibrin 1999;10 (suppl 1):S92-3.

18 Agewall S, Wikstrand J, Fagerberg B. Prothrombin fragment $1+2$ is a risk factor for myocardial infarction in treated hypertensive men. J Hypertension 1998;16:537-41.

19 Ridker PM, Buring JE, Shih J, Matias M, Hennekens CH. Prospective study of C-reactive protein and the risk of future cardiovascular events among apparently healthy women. Circulation 1998;98:731-3.

20 Witherell HL, Smith KL, Ley C, Freidman GD, Orentreich N, Vogelman $\mathrm{JH}$. Helicobacter pylori infection, C-reactive protein, and risk for myocardial infarction: a prospective study. Gastroenterology 1999;116:A355.

21 Roivainen M, Viik-Kajarnder M, Palosuo T, Sacks F Braunwald E. Infections, inflammation, and the risk of coronary heart disease. Circulation 2000;101:257.

22 Ridker PM, Rifai N, Pfeffer MA, Toivanen P, Leinonen M, Saikku P, et al. Inflammation, pravastatin, and the risk of coronary events after myocardial infarction in patients with average cholesterol levels. Circulation 1998;98:839-44.

23 Ridker PM, Cushman M, Stampfer MJ, Tracy RP, Hennekens CH. Inflammation, aspirin, and the risk of cardiovascular disease in apparently healthy men. New Enol J Med 1997;336:973-9.

24 Koenig W, Sund M, Frohlich M, Fischer HG, Lowel H, Doring A, et al. C-reactive protein, a sensitive marker of inflammation, predicts future risk of coronary heart disease in initially healthy middle-aged men: results from the MONICA-Augsburg cohort study, 1984-1992. Circulation 1999;99:237-42.

25 Kuller LH, Tracy RP, Shaten J, Meilahn EN. Relation of C-reactive protein and coronary heart disease in the MRFIT nested case-control study. Am J Epidemiol 1996;144:537-47.
26 Tracy RP, Lemaitre RN, Psaty BM, Ives DG, Evans RW, Cushman M, et al. Relationship of C-reactive protein to risk of cardiovascular disease in the elderly: results from the cardiovascular health study and the rural health promotion project. Arterioscler Thromb Vasc Biol 1997;17:1121-7.

27 Toss H, Lindahl B, Siegbahn A, Wallentin L. Prognostic influence of increased fibrinogen and C-reactive protein levels in unstable coronary artery disease Circulation 1997.96:4904-10.

28 Haverkate F, Thompson SG, Pyke SDM, Gallimore JR, Pepys MB. Production of C-reactive protein and risk of coronary events in stable and unstable angina. Lancet 1997;349:462-6.

29 Zhang YX, Cliff WJ, Schoefl GI, Higgins G. Coronary C-reactive protein distribution: its relation to development of atherosclerosis. Atherosclerosis 1999;145:375-9.

30 Cermak JC, Key NS, Bach RR, Balla J, Jacob HS, Vercellotti GM. C-reactive protein induces human peripheral blood monocytes to synthesize tissue factor. Blood 1993;82:513-20.

31 de Beer FC, Soutar AK, Baltz ML, Trayner I, Feinstein A, Pepys MB. Low density and very low density lipoproteins are selectively bound by aggregated C-reactive protein. J Exp Med 1982;156:230-42.

32 Bhakdi S, Torzewski M, Klouche M, Hemmes M. Complement activation and atherogenesis. Binding of CRP to degraded, nonoxidised LDL enhances complement activation. Arterioscler Thromb Vasc Biol 1999;19:2348-54.

33 Cushman M, Legault C, Barrett-Connor EL, Stefanick ML, Kessler C, Judd HL, et al. Effect of postmenopausal hormones on inflammationsensitive proteins: the postmenopausal estrogen/ progestin interventions (PEPI) study. Circulation 1999;100:717-22.

34 Ridker PM, Hennekens CH, Buring JE, Rifai N. C reactive protein and other markers of inflammation in the prediction of cardiovascular disease in women. N Engl J Med 2000;342:836-43.

(Accepted 22 February 2000)

\title{
Chlamydia pneumoniae infection and mortality from ischaemic heart disease: large prospective study
}

\author{
N J Wald, M R Law, J K Morris, X Zhou, Y Wong, M E Ward
}

Editorial by Koenig
BUPA
Epidemiological
Research Group,
Wolfson Institute of
Preventive
Medicine, St
Bartholomew's and
the Royal London
School of Medicine
and Dentistry,
London
EC1M 6BQ
NJ Wald
professor
M R Law
reader
J K Morris
statistician
Molecular
Microbiology
Group,
Southampton
General Hospital,
Southampton
SO16 6YD
X Zhou
research assistant
Y Wong
research registrar
M E Ward
professor
Correspondence to:
NJ Wald
n.j.wald@mds.
qmw.ac.uk

BMJ 2000;321:204-7

\section{Abstract}

Objective To determine whether there is an independent association between infection with Chlamydia pneumoniae and ischaemic heart disease. Design Prospective study using a nested case-control design.

Setting Medical centre in London run by BUPA, a private medical organisation.

Participants 21520 professional men aged 35-64 who attended for a medical examination in London between 1975 and 1982.

Main outcome measure Death from ischaemic heart disease.

Results The distributions of concentrations of IgG and IgA antibodies to C pneumoniae were similar in the 647 men who subsequently died of ischaemic heart disease and in 1294 age matched controls who did not. There was no material association with heart disease irrespective of the cut-off point chosen to define seropositivity. At a cut-off point that defines $15 \%$ of controls as positive, for example, the odds ratios were $1.26(95 \%$ confidence interval 0.95 to 1.68$)$ for IgG and 1.09 (0.82 to 1.43) for IgA.

Conclusions No material association was found between infection with $C$ pneumoniae and ischaemic heart disease. The size and prospective design of the study and the socioeconomic homogeneity of the cohort minimise both random and systematic error.

\section{Introduction}

Several reports have linked ischaemic heart disease with various infections, notably those caused by Helicobacter pylori and Chlamydia pneumoniae (also called
Chlamydophila pneumoniae). ${ }^{12}$ A review in 1997 emphasised the problems in interpreting these associations. ${ }^{2}$ The studies showing associations tended to be small, retrospective, and susceptible to bias or confounding. It was concluded that large prospective studies of socially homogeneous cohorts were needed to resolve the issue. ${ }^{2}$ We then reported a clearly negative result in much the largest study to report on the association between $H$ pylori and ischaemic heart disease, with 648 deaths. ${ }^{3}$ The prospective design of this study reduced bias, and the likelihood of an indirect association arising through differences in social class (socioeconomically disadvantaged people being more likely to have the infection and to develop heart disease regardless of a possible causal link between the two) was minimised by the homogeneity of the study population; the participants were all professional men attending for a routine medical examination. Both random and systematic errors were therefore likely to be small.

The studies of $C$ pneumoniae and heart disease have generated mixed results regardless of whether IgG or IgA was measured. ${ }^{124-11}$ For example, results from the Caerphilly prospective study were negative for IgG antibodies to chlamydia but suggested an association with IgA (odds ratio for fatal ischaemic heart disease $1.83,95 \%$ confidence interval 1.17 to 2.85$){ }^{7}$ We report on the relation between ischaemic heart disease and both IgG and IgA antibodies to C pneumoniae in the BUPA study.

\section{Participants and methods}

The study design was as reported previously for H pylori and ischaemic heart disease. ${ }^{3}$ Briefly, the BUPA 


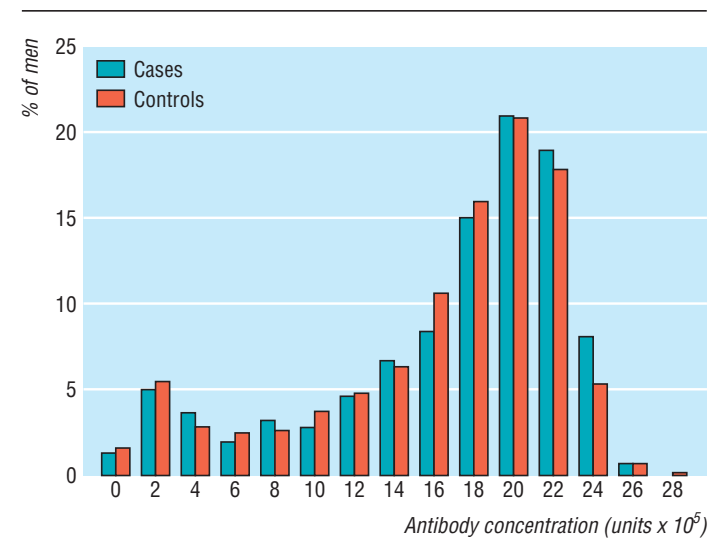

Fig 1 Distribution of serum concentration of IgG antibodies to Chlamydia pneumoniae, expressed as fluorescent counts (arbitrary units), in 647 men who died of ischaemic heart disease and 1294 matched controls who did not

study is a prospective (cohort) study of 21520 healthy professional men aged 35-64 who attended the BUPA (a private medical organisation) centre in London for a routine medical examination between 1975 and 1982. Risk factors for ischaemic heart disease were measured, and serum samples were stored at $-40^{\circ} \mathrm{C}$. At the end of 1994 (average follow up 15.6 years), 648 men with no history of heart disease on entry had died from ischaemic heart disease as defined by codes 410414 of ICD-9 (international classification of diseases, 9 th revision). Two controls were selected for each case, matched for age and duration of storage of the serum sample. For one case there was an insufficient quantity of serum remaining: this was omitted along with the two controls, leaving 647 cases and 1294 controls.

The frozen serum samples were retrieved; analyses were performed without knowledge of whether they came from cases or controls. IgG antibodies to $C$ pneumoniae were measured with a time resolved fluoroscopic immunoassay, which has been validated against the microimmunofluorescence antibody test. ${ }^{12}$ IgA antibodies were similarly measured using $1: 1000 \alpha$ chain specific goat antihuman IgA labelled with biotin (Kierkegaard and Perry, Gaithersberg, MD, USA). Antibody concentrations were expressed as fluorescence counts (arbitrary units) and typically show a bimodal distribution.

The statistical analysis was as reported previously for $H$ pylori and ischaemic heart disease. ${ }^{3}$ We used Cox's proportional hazards models, taking account of both the matching and the survival time.

\section{Results}

The established risk factors for ischaemic heart disease were, as expected, associated with ischaemic heart disease in our population, ${ }^{3}$ and the associations were similar in magnitude to those reported in other large cohort studies. The data are as previously shown, ${ }^{3}$ except that the average values for serum cholesterol concentration should have been 6.7 and $6.3 \mathrm{mmol} / \mathrm{l}$ respectively (not 7.1 and 6.7).

Examination of the association between antibody concentrations to $C$ pneumoniae and mortality from heart disease is complicated by the fact that there is no agreed or validated cut-off point for concentrations of IgG or IgA that identifies individuals who have and have not been infected with $C$ pneumoniae. Consequently, there is no accepted indication as to what proportion of the adult population has been infected. We have therefore presented our results as distributions of antibody concentrations in the 647 men who died of heart disease and the 1294 that did not. The distributions of concentrations for $\operatorname{IgG}$ and $\operatorname{IgA}$ antibodies in cases and controls are shown in figures 1 and 2 respectively. For both antibodies the distributions in cases and controls are similar. Whatever antibody concentration is chosen to define IgG or IgA seropositivity, there is little difference between the proportions of cases and controls who are positive for $C$ pneumoniae.

The main risk factors for ischaemic heart disease were similar in people with and without IgA or IgG antibody to $C$ pneumoniae, confirming that any confounding is likely to be minimal. Table 1 shows the values of the risk factors according to antibody status when the cut-off point to define positivity is taken as the 85th percentile of antibody concentrations among the controls-that is, a positive rate of $15 \%$ among the controls. The only statistically significant association with antibody concentration (at the $1 \%$ level because many comparisons were made) was a lower concentration of IgA on average in men whose father had died of ischaemic heart disease. Although this was almost certainly a chance association, it was allowed for in the statistical analysis. Using the antibody cut-off points that define $15 \%$ of controls as seropositive, the odds of death from ischaemic heart disease were $1.26(95 \%$ confidence interval, 0.95 to 1.68 ) for IgG antibody and 1.09 (0.82 to 1.43 ) for IgA antibody.

Table 2 shows the proportions of cases and controls above a range of cut-off points of antibody concentrations used to define seropositivity, from figures 1 and 2, and the associated odds ratio for death from ischaemic heart disease for each cut-off point. (Although it is usual when considering a possible relation between a risk factor and a disease to assess risk at different levels of exposure in relation to a baseline risk of one in the unexposed category, this procedure was not followed because there is no clear cut-off point for antibody to chlamydia that defines an unexposed

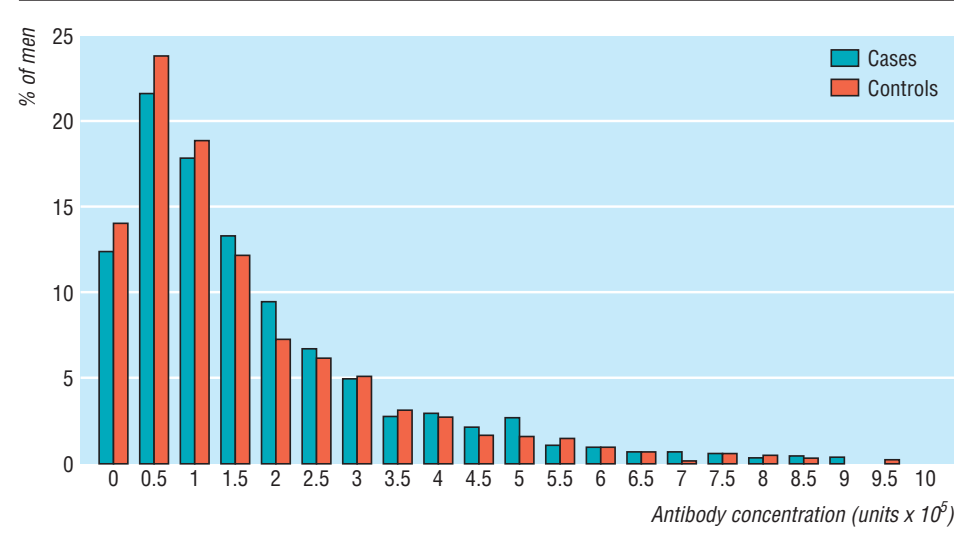

Fig 2 Distribution of serum concentration of IgA antibodies to Chlamydia pneumoniae, expressed as fluorescent counts (arbitrary units), in 647 men who died of ischaemic heart disease and 1294 matched controls who did not 
Table 1 Risk factors for heart disease according to antibody status to Chlamydia pneumoniae in 1294 men who did not die of ischaemic heart disease (controls). Values are means (standard deviations) unless stated otherwise

\begin{tabular}{|c|c|c|c|c|}
\hline & $\operatorname{Ig} G$ & & $\operatorname{Ig} A$ & ody \\
\hline & Negative $(n=1100)$ & Positive ( $n=194)$ & Negative $(n=1100)$ & Positive $(n=194)$ \\
\hline Age (years) & $53.4(7.1)$ & $54.0(7.0)$ & $53.4(7.1)$ & $54.1(6.7)$ \\
\hline Body mass index $\left(\mathrm{kg} / \mathrm{m}^{2}\right)$ & $25.4(2.7)$ & $25.4(2.6)$ & $25.3(2.7)$ & $25.6(2.8)$ \\
\hline Total cholesterol concentration $(\mathrm{mmol} / \mathrm{l})$ & $6.3(1.1)$ & $6.4(1.2)$ & $6.3(1.1)$ & $6.3(1.1)$ \\
\hline Triglyceride concentration $(\mathrm{mmol} / \mathrm{l})$ & $1.50(1.67)^{\star}$ & $1.53(1.64)^{*}$ & $1.51(1.67)^{\star}$ & $1.51(1.65)^{*}$ \\
\hline Systolic blood pressure (mm Hg) & $135(19)$ & $135(20)$ & $135(19)$ & $135(20)$ \\
\hline Diastolic blood pressure $(\mathrm{mm} \mathrm{Hg})$ & $84(12)$ & $84(11)$ & $84(12)$ & $85(13)$ \\
\hline No (\%) current cigarette smokers & $412(37)$ & $81(42)$ & $421(38)$ & $73(38)$ \\
\hline No (\%) whose father died of heart disease & $158(14)$ & $23(12)$ & $164(15)$ & $17(9)$ \\
\hline No $(\%)$ whose mother died of heart disease & $69(6)$ & $18(9)$ & $74(7)$ & $13(7)$ \\
\hline
\end{tabular}

*Geometric mean (standard deviation expressed as multiple of geometric mean).

Table 2 Odds of death from ischaemic heart disease according to antibody level in men who were positive for Chlamydia pneumoniae compared with men who were negative. Results are adjusted for IgA antibody for father dying of ischaemic heart disease

\begin{tabular}{|c|c|c|c|}
\hline $\begin{array}{l}\text { Antibody concentration* } \\
\text { (units } \times 10^{5} \text { ) }\end{array}$ & $\begin{array}{c}\text { Cases } \\
(n=647) \dagger\end{array}$ & $\begin{array}{c}\text { Controls } \\
(n=1294) \dagger\end{array}$ & Odds ratio $(95 \% \mathrm{Cl})$ \\
\hline \multicolumn{4}{|l|}{ IgG antibody } \\
\hline$\geqslant 11$ & 84 & 84 & 1.01 (0.78 to 1.31$)$ \\
\hline$\geqslant 14$ & 78 & 77 & 1.07 (0.85 to 1.35$)$ \\
\hline$\geqslant 17$ & 68 & 66 & 1.15 (0.92 to 1.43$)$ \\
\hline$\geqslant 20$ & 48 & 44 & 1.24 (0.99 to 1.54$)$ \\
\hline$\geqslant 23$ & 15 & 13 & 1.27 (0.94 to 1.71$)$ \\
\hline$\geqslant 26$ & 1 & 1 & 0.87 (0.24 to 3.11$)$ \\
\hline \multicolumn{4}{|l|}{ IgA antibody } \\
\hline$\geqslant 0.75$ & 78 & 74 & 1.26 (1.00 to 1.58$)$ \\
\hline$\geqslant 1.5$ & 48 & 43 & 1.27 (1.04 to 1.55$)$ \\
\hline$\geqslant 2.25$ & 29 & 27 & 1.17 (0.93 to 1.47$)$ \\
\hline$\geqslant 3.0$ & 19 & 18 & 1.10 (0.85 to 1.43$)$ \\
\hline$\geqslant 3.75$ & 12 & 11 & 1.14 (0.84 to 1.56$)$ \\
\hline$\geqslant 4.5$ & 9 & 7 & 1.22 (0.85 to 1.74$)$ \\
\hline
\end{tabular}

${ }^{*}$ Concentration used to define men positive for $C$ pneumoniae. †Proportion positive.

group.) Table 2 shows that whether a small or large proportion of controls are considered seropositive, there is no strong relation between infection with $C$ pneumoniae and mortality from heart disease. The data provide no convincing evidence of an association, but they do not rule out a weak association with IgG antibody.

\section{Discussion}

Our study is the largest published prospective study on $C$ pneumoniae and ischaemic heart disease. It also reduces confounding by socioeconomic status because the study population was socially homogeneous. The prospective design of our study, and the fact that the men with known ischaemic heart disease were excluded, avoids the possibility of spurious associations arising because antibodies to heart muscle proteins developing after myocardial infarction may be indistinguishable from antibodies to $C$ pneumoniae. ${ }^{4}$ The laboratory staff did not know which samples were from cases and which were from controls, and the assays involved no subjective interpretation because they were read by machine, problems that may affect other studies. The results were similar irrespective of the cut-off point chosen to define positivity. No method of detecting antibody to $C$ pneumoniae is entirely specific: we chose the delayed fluorescence assay because of its objectivity and suitability to large scale testing, but it has been validated against the classic microimmunofluorescence test for IgG antibody to chlamydia. ${ }^{12}$ Confirmation of the expected increasing prevalence of chlamydia infection with age also served as a means of validating the assay.

Table 3 summarises the results of six published cohort studies of infection with $C$ pneumoniae and the incidence of ischaemic heart disease. The US physicians study has the most cases after the BUPA study and, like it, was able to minimise confounding through differences in social class because of the socioeconomic homogeneity of the cohort; this study showed no suggestion of an association between concentrations of IgG antibodies and ischaemic heart disease. All the studies except the Caerphilly one ${ }^{7}$ suggest no material association between concentration of IgA antibody and ischaemic heart disease. Even in the Caerphilly study, ${ }^{7}$ no association was seen in relation to

Table 3 Results of published cohort studies of Chlamydia pneumoniae and incidence of ischaemic heart disease

\begin{tabular}{|c|c|c|c|c|c|c|c|}
\hline \multirow[b]{2}{*}{ Study } & \multirow[b]{2}{*}{ Cases } & \multirow[b]{2}{*}{$\begin{array}{l}\text { No of } \\
\text { cases }\end{array}$} & \multirow[b]{2}{*}{$\begin{array}{c}\text { No of } \\
\text { controls }\end{array}$} & \multicolumn{2}{|c|}{ IgG antibody } & \multicolumn{2}{|c|}{ IgA antibody } \\
\hline & & & & $\begin{array}{c}\text { Positive } \\
\text { controls (\%) }\end{array}$ & $\begin{array}{c}\text { Odds ratio } \\
(95 \% \mathrm{CI})\end{array}$ & $\begin{array}{c}\text { Positive } \\
\text { controls (\%) }\end{array}$ & $\begin{array}{c}\text { Odds ratio } \\
(95 \% \mathrm{Cl})\end{array}$ \\
\hline Helsinki ${ }^{4}$ & Death from ischaemic heart disease, non-fatal infarct & 87 & 87 & 22 & 2.1 (0.9 to 5.2$)$ & 14 & $1.1(0.5$ to 2.7$)$ \\
\hline US physicians $^{6}$ & Death from ischaemic heart disease, non-fatal infarct & 343 & 343 & 22 & $1.0(0.7$ to 1.5$)$ & NM & \\
\hline Caerphilly (United Kingdom) ${ }^{7}$ & Death from ischaemic heart disease & 144 & 1057 & 21 & $1.05(0.70 \text { to } 1.59)^{*}$ & 20 & $1.83(1.17$ to 2.85$)$ \\
\hline Caerphilly (United Kingdom) ${ }^{7}$ & Non-fatal infarct & 134 & 1057 & 21 & $0.76(0.48 \text { to } 1.22)^{*}$ & 20 & $0.70(0.43 \text { to } 1.14)^{\star}$ \\
\hline Finland $^{8}$ & Death from ischaemic heart disease, non-fatal infarct & 311 & 1682 & $\dagger$ & $\dagger$ & $16+$ & $1.19(0.71 \text { to } 2.00)^{\star}$ \\
\hline Framingham (United States) ${ }^{9}$ & Death from ischaemic heart disease, non-fatal infarct, stroke & 188 & 1315 & 47 & 0.89 (0.66 to 1.19$)$ & NM & \\
\hline Present & Death from ischaemic heart disease & 647 & 1294 & 15 & $1.26(0.95$ to 1.68$)$ & 15 & $1.09(0.82$ to 1.43$)$ \\
\hline
\end{tabular}

NM=not measured.

${ }^{*}$ Calculated by us from published data, unadjusted for confounding factors.

$\nmid 20 \%$ were IgA positive, but only those who were also IgG positive were considered positive for $C$ pneumoniae. 


\section{What is already known on this topic}

Several reports have linked ischaemic heart disease with various infections, such as with Chlamydia pneumoniae

\section{What this study adds}

The distribution of concentrations of IgG and IgA antibodies to $C$ pneumoniae were similar in men who did and did not die of ischaemic heart disease

The study is the largest to report on the association, with 647 deaths from ischaemic heart disease, and minimises the likelihood of an indirect association arising through differences in social class because the men were of similar socioeconomic status

No important relation was found between infection with $C$ pmeumoniae and ischaemic heart disease

non-fatal myocardial infarction, and the association in relation to fatal cases relied on not measuring concentrations of IgA antibodies in serum specimens with low concentrations of IgG antibodies (assuming they were all negative for IgA antibody). In an additional cohort study ${ }^{10}$ there was "no significant association" between mortality from ischaemic heart disease (67 deaths) and concentration of IgG or IgA antibody. Another study recording a mixture of incident (76) and prevalent (212) cases showed no association with $C$ pneumoniae IgG seropositivity. ${ }^{11}$ In a cohort of people enrolled with a health maintenance organisation, use of antibiotics active against $C$ pneumoniae did not reduce the incidence of first myocardial infarction during the next five years. ${ }^{13}$ Taken together, the evidence does not favour any important relation between ischaemic heart disease and infection with $C$ pneumoniae.

We thank Tiesheng Wu for computing assistance.
Contributors: NJW collected the BUPA data. NJW and MRL designed the study and analysed the results with JKM. NJW MRL, and JKM drafted the manuscript. MEW, YW, and XZ performed the serological analyses and redrafted the manuscript. NJW will act as guarantor for the paper.

Funding: The Wolfson Institute group was supported by the BUPA Medical Foundation, and the Southampton group was supported by the British Heart Foundation.

Competing interests: None declared.

1 Patel P, Mendall MA, Carrington D, Strachan DP, Leatham E, Molineaux $\mathrm{N}$, et al. Association of Helicobacter pylori and Chlamydia pneumoniae infections with coronary heart disease and cardiovascular risk factors. BMJ 1995;311:711-4

2 Danesh J, Collins R, Peto R. Chronic infections and coronary heart disease: is there a link? Lancet 1997;350:430-6.

3 Wald NJ, Law MR, Morris JK, Bagnall AM. Helicobacter pylori infection and mortality from ischaemic heart disease: negative result from a large prospective study. BMJ 1997;315:1199-201.

4 Saikku P, Leinonen M, Tenkanen L, Linnanmaki E, Ekman M-R, Manninen V, et al. Chronic Chlamydia pneumoniae infection as a risk factor for coronary heart disease in the Helsinki heart study. Ann Intern Med 1992;116:273-8.

5 Ossewaarde JM, Feskens EJM, De Vries A, Vallinga CE, Kromhout D. Chlamydia pneumoniae is a risk factor for coronary heart disease in symptom-free elderly men, but Helicobacter pylori and cytomegalovirus are not. Epidemiol Infect 1998;120:93-9.

6 Ridker PM, Kundsin RB, Stampfer MJ, Poulin S, Hennekens CH Prospective study of Chlamydia pneumoniae IgG seropositivity and risk of future myocardial infarction. Circulation 1999;99:1161-4.

7 Strachan DP, Carrington D, Mendall MA, Ballam L, Morris J, Butland BK, et al. Relation of Chlamydia pneumoniae serology to mortality and incidence of ischaemic heart disease over 13 years in the Caerphilly prospective heart disease study. BMJ 1999;318:1035-40.

8 Miettinen H, Lehto S, Saikku P, Haffnet SM, Ronnemaas T, Pyorola K, et al. Association of Chlamydia pneumoniae and acute coronary heart disease events in non-insulin dependent diabetic and non-diabetic subjects in Finland. Eur Heart J 1996;17:682-8.

9 Haider AW, Wilson PWF, Larson MG, Sutherland P, Evans JC, O'Donnel $\mathrm{CJ}$, et al. Chlamydia, $\mathrm{H}$ pylori and cytomegalovirus seropositivity and risk of cardiovascular disease: the Framingham Heart Study. J Am Coll Cardiol 1999;33:314A.

10 Von Hertzen L, Isoaho R, Kivelä SL, Saikku P. Relation of C pneumoniae antibodies to ischaemic heart disease. BMJ 1999;319:1575-6.

11 Danesh J, Wong Y, Wart M, Muir J. Chronic infection with Helicobacte pylori, Chlamydia pneumoniae, or cytomegalovirus: population based study of coronary heart disease. Heart 1999;81:245-7.

12 Wong YK, Sueur JM, Fall CHD, Orfila J, Ward ME. The species specificity of the microimmunofluorescence antibody test and comparisons with a time resolved fluoroscopic immunoassay for measuring $\operatorname{IgG}$ antibodies against Chlamydia pneumoniae. J Clin Pathol 1999;52:99-102.

13 Jackson LA, Smith NL, Heckbert SR, Grayston JT, Siscovick DS, Psaty BM. Lack of association between first myocardial infarction and past use of erythromycin, tetracycline, or doxycycline. Emerg Infect Dis 1999;5:281-4.

(Accepted 15 March 2000)

\section{A memorable patient \\ The danger of a high $\mathrm{C}$}

While about to take blood, I noticed a thin scar running along the left elbow of my elderly patient in exactly the place I would have liked to venesect him. I asked him how he got the scar and was bemused by the reply: "That is from when I broke my neck playing the 'Tiger Rag.' I questioned him further. The events occurred in 1945, when he was posted to Burma. Shortly before the war ended, he was travelling in a jeep that came off the road and rolled over. Apart from a deep cut in his left arm, he recovered quickly and was discharged from the field hospital after a week of convalescence.

While he was on leave awaiting transport back to Britain, he heard the sound of music from a dance hall, and when he went inside he came across a rather morose dance band in rehearsal. The trumpet player, they explained gloomily, had been killed on duty-they still had his trumpet-but they were due to do a concert and were lost without the trumpeter. My patient explained that he had a passion for the trumpet, and was actually rather good at playing by ear. The band recruited him with glee, and all went well until they came to rehearse the opening number, the "Tiger Rag."
At a certain point the trumpet player has to hit a deafeningly high C. When this point came, he played the note, and the next thing he remembered was waking up in hospital.

Unbeknown to him, the original jeep accident had caused him to fracture two vertebrae, which remained relatively stable until the extreme pressure of the "Tiger Rag" caused them to destabilise. He was in a body plaster for four months, and it was a while before he returned to trumpet playing.

Georgia Ingram surgical house officer, Norwich

We welcome articles of up to 600 words on topics such as A memorable patient, A paper that changed my practice, My most unfortunate mistake, or any other piece conveying instruction, pathos, or humour. If possible the article should be supplied on a disk. Permission is needed from the patient or a relative if an identifiable patient is referred to. We also welcome contributions for "Endpieces," consisting of quotations of up to 80 words (but most are considerably shorter) from any source, ancient or modern, which have appealed to the reader. 